\title{
A Contrastive Analysis of the Order of Combination of the Components in Coordinate Compounds in the Korean and Vietnamese Languages
}

\author{
Tran Thi Lan Anh \\ Thang Long University, Hanoi, Vietnam
}

\begin{abstract}
Coordinate compounds are compounds in which the constituent components are grammatically equivalent. This study focuses on the contrastive analysis of the combination order of the words" constituent components making up coordinate compounds in both the Korean and Vietnamese languages to find the differences as well as similarities under the lens of cognitive linguistics. Specifically, this study looks into the combination order of the compounds" constituent components through the system of the senses - cognition through sensory perception, psychological mechanism - psychological cognition and social cognition of the Korean and Vietnamese people.
\end{abstract}

Keywords: compound, coordinate compound, Korean, Vietnamese, cognitive, cognition through sensory perception, psychological cognition, social cognition

\section{Introduction}

Coordinate compounds are compounds in which the constituent components are grammatically equivalent. Coordinate compounds exist in both Korean and Vietnamese, for example: "밤낮" in Korean is a coordinate compound composed of two components "밤—night" and "낮— day"; in Vietnamese, there is a similar coordinate compound which is "ngày đêm (đêm ngày)" (day \& night/night \& day). Another example is the compound "여기저기" which is a coordinate compound made out of two components "여기-here" and "저기-there"; in Vietnamese, there is a similar compound which is "đây đó" (here \& there). One more example is the coordinate compound "오가다" which is the combination of two verbs "오다—come" and "가다—go"; similarly, in Vietnamese, there is an equivalent compound which is "đi lại" (go \& come). With just these three coordinate compounds, it can be seen that there are differences in the order of combination of the components in the coordinate compounds in both Korean and Vietnamese. "밤낮" has the combination order of "night \& day"; in Vietnamese, this could either be "day \& night" or "night \& day", but "day \& night" is a more natural order and more commonly used. As for the coordinate compound "여기저기—here \& there", there is a similarity in the order of combination. "오가다" shows a clearer difference; in Korean the order of combination is "come \& go" while in Vietnamese, that order is reversed as "đi đến" (go \& come), which is more accurately translated to "đi lại". Thus, in the process of making compounds, especially compounds whose constituent components have an equal relationship, the psycho-physiological state of the language users are clearly reflected in the combination order of those components. Most of the combination orders in Korean and

Tran Thi Lan Anh, Ph.D., Professor, Department of Korean Language, Thang Long University. 
Vietnamese are relatively fixed, in a few cases the combination order can be reversed but such cases are rare and uncommon. If the combination order of constituent components making up coordinate compounds in Korean and Vietnamese is compared, it can be seen that there are many similarities and differences. It can be said that such similarities or differences reflect the psychological mechanism of the Korean and Vietnamese people; in other words, the cognition of the objective world of the Korean and Vietnamese people is specifically reflected through language. This study focuses on the contrastive analysis of the combination order of the words" constituent components making up coordinate compounds in both the Korean and Vietnamese languages to find the differences as well as similarities under the lens of cognitive linguistics. Specifically, this study looks into the combination order of the compounds" constituent components through the system of the senses—cognition through sensory perception, psychological mechanism—psychological cognition and social cognition of the Korean and Vietnamese people.

\section{The Combination Order of Components of Coordinate Compounds in Korean and Vietnamese Under the Lens of Cognitive Linguistics}

Cognitive linguistics,

is a new school of modern linguistics which conducts linguistic research on the basis of human experience and perception of the objective world as well as the way in which humans conceptualize and categorize the objects and events of that objective world. (Ly, 2009, p. 13)

Thus, it can be said that cognitive linguistics is not a branch of linguistics but a new school of linguistics, a new research direction of modern linguistics. Languages at its inception have reflected the thought and thinking of humans, in other words, humans express feelings or describe symbols and images with concepts through languages.

Unlike traditional linguistics which holds the view that languages open the door into the objective world, cognitive linguistics helps us to realize that languages are "the door into the spiritual world of humans". Each country, people or individual has one"s own perception of the objective reality depending on the geographical characteristics and regional cultures of each nation or people. For example, Vietnam and Korea are both Asian countries influenced by Confucianism, thus the way the Vietnamese and Korean people perceive the objective world as reflected through their language has many similarities, such as the idea of respecting the elderly, senior people, people of a higher status, or the idea of valuing men more than women. These ideas are clearly shown through such coordinate compounds as "어이아들" (mother \& son), "어비딸" (father \& daughter), “남녀” (male \& female), and “아들딸” (son \& daughter). In Vietnamese, there are "cha con" (father \& child), "mẹ con" (mother \& child), "ông cháu" (grandfather \& grandchild), "anh em" (older brother \& younger brother), "chị em" (older sister \& younger sister), "nam nữ" (male \& female), "anh chị” (older brother \& older sister), "trai gái" (boy \& girl), etc. The order of the components in the above compounds clearly show the similarities in the thinking as well as the perception of the objective world of Korean and Vietnamese people, which are: older people, people of higher status are always placed before; younger people, people of lower status are placed after. With the idea of valuing men more, the male always proceeds, and the component indicating the female always follows. Of course, in reality, there are Korean people who say "딸아들" (daughter \& son), and Vietnamese people who say "gái trai" (girl \& boy) instead of "trai gái” (boy \& girl), however, this order is used by the minority of people, the majority still follow the order of placing the male first 
and the female after, clearly reflecting the idea of male chauvinism held by the Korean and Vietnamese people.

A 1982 study by Noh Dae Gyu explains eight psychological causes reflected through the combination order of coordinate compounds such as the order of occurrence, the position of the speaker, importance, male, adult, power, positive meaning, above \& below positions, or inside \& outside positions. Most recently, in a 2010 study by Im Ji Ryong, Im also suggests that the psychological mechanism is clearly reflected through the combination order of components of coordinate compounds and also explains psychological causes such as affirmation and negation, direction, distance, gender, time, positivity, and negativity. This study shall focus on comparing the combination order of components of coordinate compounds in Korean and Vietnamese in a broad sense on three aspects which are cognitions through sensory perception, psychological cognition, and social cognition.

\section{Cognition Through Sensory Perception}

Sensory perception is a process of reflecting in full an object and objective phenomenon when they directly affect the human senses. Sensory perception helps humans to determine quite clearly the position of the subject as compared to the objects and phenomena in the surrounding world. Humans would mostly perceive the external image of the thing and phenomenon, then conceptualize into a specific object or subject, rather than focusing on abstract subjects or objects. When humans are standing, the appropriate position to perceive the surrounding world is the space in front of where they are standing and the ground on which they are standing; in such a position, humans will process information and perceive objects and phenomena more accurately and will not spend too much time on information processing. And humans always perceive space following the thinking "오른쪽 왼쪽 (right-left)", "위아래 (above-below)", "앞뒤 (in front-behind)", “오르내리다 (up \& down)", "안팎 (inside \& outside)", etc. Especially in terms of space, humans always speak of things and phenomena closest to them first before speaking of further objects. For example, Korean people often say "이것저것" (this thing \& that thing), "이곳저곳” (this place \& that place), "여기저기” (here \& there), "이쪽저쪽" ("this direction \& that direction"), "이래저래 (this way \& that way), etc. In Vietnamese, there are also similar words and ways of thinking such as "này kia" (this \& that), "đây đó" (here \& there), and "gần xa" (near \& far).

Humans when perceiving an object or phenomenon will normally only see, touch, or smell the objects and phenomena in front of themselves; if they want to perceive objects behind themselves, they will have to change their position, i.e., to turn around, thus, in this case, the space they can perceive is the space "in front of" themselves. For that reason, in Korean and Vietnamese, people always say "앞뒤” (in front \& behind), not “뒤앞” (behind \& in front). Regarding “안팎 (inside \& outside)", we can see a similar pattern; when referring to "inside \& outside", the inside space is always mentioned first because it appears first, "outside" always appears later. In terms of "inside \& outside", we also have "내외 (internal \& external)", "go out \& come in". When standing inside, we would think of the action of "going out" first before the action of "coming in". However, there are people who will say "come in \& go out", "in \& out", if that speaker is standing outside, not "inside". There is the word "출입 (exit \& entry)"; if the speaker is inside and exits to the outside, people often say “출국— to exit (a country)", and when the speaker is outside and wishes to enter a nation, he/she will say “입국—enter (a country)". People can also say "export \& import—import \& export” for goods in general; this depends on the location of the object or the speaker, whether they are "inside" or "outside" can change the order. However, when perceiving an overall space like a certain country or region, both Korean and 
Vietnamese people perceive the "inside" position before the "outside".

In terms of "above \& below", both Korean and Vietnamese consider the position and direction of vision of the perceiver; if the subject or object is suitable to be viewed in the upper position, people will speak of the "above" first; if the subject or object is suitable to be viewed by looking down, the "above" may be spoken of first, for example, "trên dưới" (up \& down), "nhà trên nhà dưới" (upper house \& lower house), "dưới trên" (below \& above), "hàm trên hàm dưới" (upper jaw \& lower jaw). As for the word "하늘 땅 (heaven \& earth)", "하늘 (heaven)" is above and holds a more positive meaning, so the Koreans always speak of the "heaven" before the "earth". The Vietnamese also say "trời đất" (heaven \& earth), but also say "đất trời" (earth \& heaven); this depends on each person's way of perception so it can be subjective.

In terms of time, a sequence of "past-present-future" is always followed, however the point in time or position of the speaker is in the present, therefore humans tend to speak of the present first, but they can also speak of the past first. For example, in Korean, there are "오늘내일" (today \& tomorrow), "내후년" (the year after next), "엊그저께” (yesterday \& the day before yesterday), "예지금" (from the past until now), etc. whereas in Vietnamese, there are "nay mai" (today \& tomorrow), " xưa nay" (from the past until now), "ngày kia ngày kìa" (the day after tomorrow $\&$ the day after that), etc.

\section{Psychological Cognition}

In the process of perceiving the objective reality, psychological cognition has considerable influence on reflecting human thinking through languages, specifically through the combination order of the components of coordinate compounds in both the Korean and Vietnamese languages, for instance, when combining the names of the two nations in such a way as "the Korea-Vietnam/Vietnam-Korea relation", "the China-Vietnam/Vietnam-China relation", "the Vietnam-Japan/Japan-Vietnam relation". If the speaker is Vietnamese, he/she will always say "the Vietnam-Korea/Vietnam-China/Vietnam-Japan relation". If the speaker is Korean, he/she tends to say "the Korea-Vietnam relation"; the Japanese will say "the Japan-Vietnam relation"; the Chinese will say "the China-Vietnam relation". Because humans always perceive the space in where they exist first, they will feel close, sympathetic, and psychologically inclined to mention that space first. Especially when speaking their country's name, they always value their own country more in their mind, so the combination order may change and reflect the subjective mindset of the speaker.

The human psychology in general and of the Vietnamese and Korean people in particular all prefer good things which carry positive, good meaning so the components indicating goodness and positivity are always placed first and the components indicating a negative, worse meaning will follow.

In Korean: 선악 (good \& bad), 승패 (success \& failure), 유무 (presence \& non-presence), 가감 (increase \& decrease), 상벌 (reward \& punishment), 생사 (life \& death), 장단 (long \& short), 존망 (existence \& non-existence), 찬반 (agreement \& objection), 미추 (beauty \& ugliness), 득실 (gain \& loss), etc.

In Vietnamese: thiện ác (good \& bad), đẹp xấu (beauty \& ugliness), thành bại (succees \& failure), gia giảm (increase \& decrease), thưởng phạt (reward \& punishment), sinh tử (life \& death), dài ngắn (long \& short), tồn vong (existence \& non-existence), ăn thua (win \& lose), được mất (gain \& loss), yêu ghét (love \& hate), may rủi (luck \& bad luck), sống chết (life \& death), etc.

Humans always love the good and gravitate towards the good, so good things are always mentioned first. Thus, the Koreans never say “악선” (bad \& good); the Vietnamese also never say "ác thiện” (bad \& good). 
Similarly, humans always want to "gain", not to "lose", so both the Koreans and the Vietnamese never say “실득" (loss \& gain) or "mất được" (loss \& gain).

Thus, both the Vietnamese and the Koreans have a fairly similar psychological mechanism. The Vietnamese and the Koreans both love beauty, good things, positive things such as "the good, success, existence, life, reward, gain", like to "win", to be "rewarded", to "gain", to receive something for themselves. Therefore, these components are always placed first, while the components indicating negative, bad meaning like "bad, failure, non-presence, decrease, punishment, death, short, non-existence, objection, ugliness, loss, hate, lose, etc." always have to follow. Most of the above compound words have a fixed order which cannot be reversed.

\section{Social Cognition}

Languages are highly social, therefore certain social values, norms or highly-regarded subjects are always reflected naturally in a language. In coordinate compounds with components indicating humans, people of higher positions or older people are always placed first, while younger people or people of lower positions are always placed behind.

In Korean: 어이아들 (mother \& son), 어이딸 (mother \& daughter), 어이며느리 (mother-in-law \& daughter-in-law), 어비아들 (father \& son), 어이자식 (mother \& child), 어비딸 (father \& daughter), 부자 (父子—father \& son), 모녀 (母女-mother \& daughter), 형제 (older brothers \& younger brothers), 자매 (older sisters \& younger sisters), etc.

In Vietnamese: cha con (father \& child), mẹ con (mother \& child), ông cháu (grandfather \& grandchild), bà cháu (grandmother $\&$ grandchild), già trẻ (old \& young), anh em (older brothers $\&$ younger brothers), chị em (older sisters \& younger sisters), thầy trò (teacher \& student), chủ tớ (master \& servant), etc.

Through the above coordinate compounds, it can be seen that the combination order of components strongly depends on the human consciousness and thinking. Both the Vietnamese and the Koreans have respect for the elderly, older people, so the components indicating older people and people of higher positions always precede the components indicating younger people or people of lower positions. But in Vietnamese, there are also exceptions, for example, the compound "chú bác"; in a family "bác" is the older uncle while "chú" is younger, but Vietnamese people rarely say "bác chú" but almost always say "chú bác". This can be considered an exception in Vietnamese, "bác chú" in the sense of sound appears to be unnatural while reversing to "chú bác" sounds more natural.

The mindset of valuing men over women is also prominent in both Vietnamese and Korean. It can be said that due to the influence of Confucianism, the combination order of components of coordinate compounds in both languages profoundly reflects this mindset.

In Korean: 남녀 (male \& female), 오누이 (brother \& sister), 아들딸 (son \& daughter), 소년소녀 (teenage boy \& teenage girl), 신랑각시 (husband \& wife), 부부 (husband \& wife), 부모 (father \& mother), 신랑신부 (groom \& bride), 신사숙녀 (gentlemen \& ladies), 형제자매 (brothers \& sisters).

In Vietnamese: nam nữ (male \& female), anh chị (brother \& sister), trai gái (boy \& girl), cậu mợ (uncle \& aunt on the mother's side), chú thím (uncle \& aunt on the father's side), etc.

In the majority of components indicating the male and female gender, the male gender often precedes the female gender in both Korean and Vietnamese. However, in Vietnamese, there are some differences. Even though Vietnam is also heavily influenced by Confucianism and has a mindset of valuing men over women, 
some coordinate compounds show a reverse order, unlike the common order. For example, in Korean, when referring to husband and wife, the "husband" component precedes the "wife" component, or the "groom" precedes the "bride". However in Vietnamese, it is not "chồng vợ" (husband \& wife) but "vợ chồng" (wife \& husband), not "chú cô" (uncle \& aunt) but "cô chú" (aunt \& uncle), and the Vietnamese often say "cô dâu chú rể" (bride \& groom); many people also say "chú rể cô dâu" (groom \& bride); this also depends on the subjective view of each person. However, this reverse order is not the norm and can be considered an exception as the "chú bác" (younger uncle \& older uncle) example above. "Trai gái" (boy \& girl) also has a special order; some people still say "gái trai" (girl \& boy) but this order is not used by the majority, mostly carrying the subjective viewpoint of the speaker; the "trai gái" (boy \& girl) order is still the natural order, accurately reflecting the human mindset and consciousness in general.

Next, the combination order of compounds' components is also affected by the components indicating subjects of higher social importance or hold more social, economic, or political power. Generally, the components indicating more powerful or important subjects will precede less powerful components.

In Korean: 총칼 (gun \& knife), 문무 (literary \& martial arts), 군경 (military \& police), 주종 (master \& servant), 문창 (main door \& window), 논밭 (field \& garden), 강약 (strength \& weakness), 공사 (public \& private), 관민 (officials \& the people), 군신 (the sovereign \& the subject), 사제 (teacher \& student), 상하 (above \& below), 주객 (host \& guest), etc.

In the Korean mindset, between guns and knives, guns are more powerful or more important; therefore the "gun" component precedes the less important, less powerful "knife" component. In Vietnamese, there is no word to denote "guns \& knives" but there is the word "súng đạn" (guns \& bullets) to denote weapons in general; however, "gun" is the bigger thing, whereas "bullets" are small parts within the gun, so the "bullets" component is appropriately placed behind. Both the Koreans and the Vietnamese value "literary" over "martial arts", so the "literary" component always precedes the "martial arts" component and this order cannot be reversed to be "võ văn" (martial arts \& literary). As for "quân thần" (sovereign \& subject), "quan dân" (officials \& people), "quân" (sovereign), "quan" (officials) are more socially, economically, and politically powerful than "thần" (subject) and "dân" (people) so the former components always precede and such combination order cannot be reversed.

The Vietnamese also attach more importance to subjects which are more powerful and more socially, economically, and politically influential, so the components that indicate these subjects will precede components indicating less powerful subjects, for instance "mạnh yếu" (strength \& weakness), "công tư" (public \& private), "vua quan" (king \& officials), "vua tôi” (king \& subject), "quan dân" (officials \& people), "quân thần" (sovereign \& subject), "thầy trò" (teacher \& student), "trên dưới” (higher \& lower), "chủ khách" (host \& guest), etc.

\section{Conclusion}

This study focuses on the contrastive analysis of the combination order of the components of coordinate compounds in the Korean and Vietnamese language under the lens of cognitive linguistics. Specifically, we make a comparison of three aspects which are cognition through sensory perception, psychological cognition, and social cognition. Perhaps because both Vietnam and Korea are Asian countries influenced by the Chinese culture, in which the ideology of Confucianism is prominent, the way the Vietnamese and Korean people perceive the surrounding world has many similarities, especially in terms of psychological and social cognition. 
It can be said that such a way of cognition has determined the combination order of the majority of coordinate compounds in Vietnamese and Korean. The idea of respecting people above oneself and showing humility to people of lower positions than oneself, the idea of valuing men over women, the gravitation towards the good, the love for beauty and the powerful are clearly expressed through the combination order of the components in compound words. The perception of space also has some similarities, for example, both the Koreans and the Vietnamese always speak of things closest to themselves first before mentioning things and phenomena further away, or they both follow the thinking patterns of "right to left", "above-below", before-after", etc.

Although the way of perceiving the objective world is the same, not all cases of the combination order of components are fixed and unchanged; in Korean, the combination order can be reversed in some cases; this depends on the subjective viewpoint of each speaker but the reverse of combination order can be said to be rare, whereas, in Vietnamese, this also depends on the tone, so the phenomenon of harmonizing the tones also has some influence on the combination order of the components in the formation of some compound words in the Vietnamese language.

\section{References}

Diep, Q. B. (2008). Ngũ pháp tiếng Việt (Vietnamese grammar). Hanoi: Education Publishing House.

Do, H. C. (1999). Các bình diện của tù và tù tiếng Việt (Aspects of words and Vietnamese words). Ho Chi Minh City: Vietnam National University Press.

Hoang, P. (2012). Tù điển tiếng Việt (Vietnamese Dictionary). Hanoi: Vietnam’s Encyclopedia Publishing House.

Hoang, V. H. (2008). Tù tiếng Việt (Vietnamese words). Ho Chi Minh: Saigon Cultural Publishing House.

Im, J. R. (2010). Ngữ nghĩa của từ và ngôn ngữ học tri nhận (Semantics and cognitive linguistics). Journal of Korean Studies, 49 , 1-35.

Kim, I. B. (2000). Nghiên cứu về tù̀ ghép tiếng Hàn (Study on the Korean compound words). Seoul: Yok Rak Publishing.

Ly, T. T. (2009). Ngôn ngũ học tri nhận-Tù li thuyết đại curong đến thực tiễn tiếng Việt (Cognitive linguistics-From general theory to the practicality of the Vietnamese language). Ca Mau: Phuong Dong Publishing House.

Noh, D. G. (1982). Nguyên tắc cấu tạo từ phức trong tiếng Hàn (Principles of forming complex words in the Korean language). Journal of Humanities, 4, 5-28.

Standard Korean Language Dictionary, National Institute of Korean Language. (1999). Retrieved from http://stdweb2.korean.go.kr/main.jsp 